during the year, mostly by gifts and exchanges. A list of Smithsonian publications during the year is appended, and these include, besides the sixth revised edition of the Smithsonian Meteorological Tables and the Smithsonian Logarithmic Tables, E. A. Goldman's "Biological Investigations in Mexico", A. H. and L. F. Clarke's "The Butterflies of Virginia" and F. Rasetti's "Middle Cambrian Stratigraphy and Faunas of the Canadian Rocky Mountains".

\section{UNIVERSITY AFFAIRS IN GREAT BRITAIN, $|95|-52$}

$\mathrm{T}$ HE "Returns from Universities and University Colleges in receipt of Treasury Grant for the Academic Year 1951-52"*, issued by the University Grants Committee, show a further decline of 1,856 in the number of full-time students- to 83,458 , compared with 85,314 in $1950-51$ and 85,421 in $1949-50$. In English universities, full-time men students decreased by 724, but women students increased by 128 ; for Wales the corresponding figures were 276 and 6, while for Scotland there were 861 fewer men and 129 fewer women. Overseas students from within the British Commonwealth increased by 264 to 3,921 full-time and 1,636 part-time students, and students from foreign countries by 137 to 3,039 fulltime and 1,320 part-time students. While the reduction in numbers of full-time students was distributed fairly generally over all faculties, except dentistry, which increased by four, from 2,885 in $1950-51$ to 2,889 in $1951-52$, it will be noted that although the largest decrease (852) was in arts students (to 35,936 ), those in pure science decressed by 115 to 17,053 , of technology by 376 to 10,215 , of medicine bv 291 to 13,910 , of agriculture by 188 to 2,418 , and of veterinary science by 38 to 1,037 . Full-time advanced students of pure science decreased by 35 to 2,858 , of medicine by 27 to 965 , of agriculture by 4 to 274 , and of veterinary science by 3 to 10 . On the other hand, full-time advanced students of technology increased by 98 to 1,105 , of dentistry by 20 to 42 , and of arts by 17 to 3,314 . Of the full-time students, 66,409 were reading for a first degree, 5,505 for a first diploma, and 11,544 were engaged in research or other advanced work, the corresponding figures for $1950-51$ being $67,743,6,244$ and 11,327 , respectively.

The proportion of assisted students was practically unchanged $(72.4$ per cent compared with 72.5 per cent in 1950-51); but although the figure for England as a whole remained unchanged, decreases at Oxford (from 75.7 to 71.7 per cent) and at Cambridge (from $\mathbf{7 4 . 3}$ to 67.8 per cent) were more than offset by increases at London (from 65.9 to 67.7 per cent) and at other universities (from 77.9 to 79.5 per cent). In Wales the percentage of assisted students increased from 85.9 to 88.3 ; but in Scotland there was a decrease from $63 \cdot 1$ to $61 \cdot 6$. The dependence on Parliamentary grants again increased, and now represents 66.5 per cent of recurrent income, compared with 64.9 per cent in $1950-51$, only 14.8 per cent coming from fees, compared with 16.6 per cent in $1950-51,5 \cdot 2$ per cent from endowments, $4 \cdot 1$ per cent from local authority grants and 1.9 per cent

* Uniyersity Grants Committee. Returns from Universities and University Colleges in receipt of Treasury Grant, Academic Year 1951-1952. (Cmd. 8847.) Pp. 44. (Iondon: H.M. Stationery Office 1953.) 28 . $6 d$. net. from donations and subscriptions, compared with $5 \cdot 5$ per cent, $4 \cdot 3$ per cent and $1 \cdot 8$ per cent, respectively, in 1950-51. The ratio of staff to students again increased, the full-time teaching staff being now 8,952 compared with 8,603 in $1950-51$ and 7,930 in 1949-50. The increase was distributed fairly generally over most grades-professors, 43 ; readers, assistant professors and independent lecturers, 8 ; senior lecturers, 71 ; lecturers, 222-but assistant lecturers and demonstrators decreased by 58 to 1,537 . Classified figures are included for the 2,454 full-time teaching staff of the University of London and for the staffs of its libraries, and the analysis of expenditure of the institutions of the University of London is now accompanied by those of the Universities of Durham and Wales.

Of the full-time students, 63,584 were in Fngland, 4,863 in Wales and 15,011 in Scotland. Of these, 15,084 were at Oxford and Cambridge, 18,312 at London, and 30,188 at other English universities and colleges. Changes at the individual universities and colleges were usually slight, only Cambridge and North Staffordshire University College (157 to 300) showing increases of more than a hundred students, and only the universities of Oxford, Liverpool and Manchester and the Manchester College of Technology decreases of more than a hundred. The proportion of full-time students residing in colleges and halls of residence increased to 25.9 per cent ; the proportion of men in residence was 21.2 per cent and of women $41 \cdot 2$ per cent, while 33,005 students $(39 \cdot 6$ per cent) were in lodgings and $28,828(\mathbf{3 4} \cdot 5$ per cent) at home. of the 22,414 students admitted for the first time in 1951-52 (an increase of 191 on 1950-51), 20,567 were reading for a first degree and 1,847 for a first diploma, and of those reading for a first degree, 1,926 were less than eighteen years of age and 11,542 were nineteen or more. There was no significant change in the distribution of full-time students compared with 1949-50 or 1950-51. Arts students again represented 43.1 per cent of the total, those in pure science $20 \cdot 4$, in medicine $16 \cdot 7$, in technology 12.4 , in dentistry $12 \cdot 5$, in agriculture $2 \cdot 9$, and in veterinary science 1.2 per cent. While the proportion of full-time advanced students of technology increased to 12.9 per cent compared with 11.8 per cent in 1950-51, there is no other sign in these returns of any response to the urgent call for more university-trained technologists, and although 25.8 per cent of full-time advanced students were working for a teacher's diploma, the contribution of the universities towards the supply of science teachers cannot be estimated from these returns. Of the full-time students, 36,745 out of $49,275 \mathrm{men}$, and 10,160 out of 14,309 women in England, were receiving assistance in the way of scholarships, exhibitions or other awards from public or private funds; for Wales, the corresponding figures are 3,154 out of 3,546 men, and 1,142 out of 1,317 women; and for Scotland, 7,275 out of 11,149 men, and 1,976 out of 3,862 women. Of 63,970 fulltime men students, 36.8 per cent were in arts, $21 \cdot 5$ per cent in pure science, $17 \cdot 2$ per cent in medicine and 15.7 per cent in technology; for the 19,488 women students the corresponding figures are $63 \cdot 3$, $17 \cdot 0,15 \cdot 1$ and 0.9 per cent. Medicine and dentistry claimed 51.1 per cent of the part-time advanced students, arts $33 \cdot 0$, technology $8 \cdot 0$, and pure science $7 \cdot 2$ per cent, compared with $44 \cdot 6,30 \cdot 4,9 \cdot 6$ and 8.7 per cent, respectively, in 1950-51.

The recurrent income of the universities and university colleges of Great Britain increased by 
$£ 1,479,876$ to $£ 25,747,999$, of which $£ 17,126,993$ was from Parliamentary grants, $£ 3,807,440$ from fees,

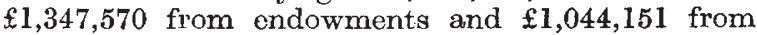
grants from local authorities. Of the total income from public funds of $£ 18,171,144$ and $£ 7,576,855$ from other sources, the University of London received $£ 5,484,932$ from public and $£ 2,146,915$ from other sources; the University of Cambridge similarly received $£ 1,141,350$ and $£ 1,161,231$; for Oxford the corresponding figures are $£ 1,010,283$ and $\mathfrak{f} 684,469$; for Manchester, $£ 947,752$ and $£ 276,832$; for Birmingham, $£ 784,576$ and $£ 251,156$; for Durham, $£ 779,311$ and $£ 326,310$; for Leeds, $£ 766,052$ and $£ 266,472$; for Liverpool, $£ 719,115$ and $£ 233,220$; for Bristol, $£ 684,082$ and $£ 313,864$; and for Sheffield, $£ 497,520$ and $£ 156,079$. No other English university or university college had an income exceeding half a million pounds, but all four universities in Scotland exceeded this figure: Aberdeen, with $£ 432,750$ from public and $£ 137,453$ from other sources; Edinburgh, with $£ 840,906$ and $£ 354,792$; Glasgow, with $£ 894,950$ and $£ 349,042$; and St. Andrews, including Dundee University College, with $£ 413,400$ and $£ 112,640$, respectively. The University of Wales, including the Welsh National School of Medicine, received $£ 900,678$ from public funds, and $£ 320,893$ from other sources,

Of the total expenditure of $£ 26,132,122$, an increase of $£ 2,098,937$ on the previous year, administration accounted for 8.8 per cent, departmental maintenance $69 \cdot 3$, maintenance of premises $11 \cdot 4$, and miscellaneous expenditure 9.5 per cent. Capital expenditure met from income amounted to $£ 258,963$ and allocations to reserves to $£ 222,536$; for $1950-51$ these figures were $£ 254,274$ and $£ 236,707$, respectively. Departmental maintenance included salaries of teaching and research staff and payments for superannuation, the running costs of laboratories, lecture rooms, libraries and museums, and the supply of materials, apparatus, books, specimens, etc. Salaries and superannuation amounted to $£ 12,542,994$ compared with $£ 11,895,971$ in $1950-51$; this represents 48 per cent of the total expenditure compared with $49 \cdot 1$ per cent in $1950-51$, with a 4 per cent increase in full-time staff.

Library expenditure, excluding general maintenance of library buildings, etc., rates, heat, light, repairs, etc., amounted to $£ 988,029$, or $3 \cdot 8$ per cent of the total expenditure, compared. with $£ 891,385$ and $3 \cdot 7$ per cent in $1950-51$. Of this total, $£ 527,238$ was for salaries and wages, £202,567 on account of books, $£ 118,702$ on periodicals and $£ 85,087$ on bindings. The University of Oxford spent $£ 27,160$ on books, Cambridge $£ 11,623$ and Manchester $£ 10,924$, while a total of $£ 53,730$, including $£ 7,478$ on the Central Library, $\mathfrak{1 4 , 7 8 7}$ at the London School of Economics, $£ 5,713$ at the School of Oriental and African Studies, and $£ 6,425$ at University College, was expended for this purpose in the schools and colleges of the University of London. Ten other universities, Birmingham (£6,574), Bristol (£5,689), Durham $(£ 6,328)$, Leeds $(£ 7,377)$, Liverpool $(£ 8,110)$, Reading $(£ 7,582)$, Aberdeen (£5,818), Edinburgh (£7,686), Glasgow $(£ 9,326)$ and St. Andrews $(£ 5,163)$, spent $£ 5,000$ or more on books; and London $(£ 35,435)$, Oxford $(\mathfrak{l} 8,953)$, Cambridge $(\mathfrak{f} 8,641)$, Clasgow $(\mathfrak{f} 8,258)$ Edinburgh $(£ 5,677)$ and Manchester $(£ 5,193)$ spent a similar sum on periodicals. The University of Wales, including the Welsh Natjonal School of Medicine, spent $£ 7,987$ on books and $£ 6,167$ on periodicals.

\section{DUTCH-NORWEGIAN JOINT ESTABLISHMENT FOR NUCLEAR ENERGY RESEARCH}

$\mathrm{T}$

HE Dutch-Norwegian co-operative effort in the field of atomic energy was established in April 1951, and its initial aim was the completion of the heavy-water uranium reactor, Joint Establishment Experimental Pile (JEEP), which was under construction at Kjeller, Norway. In order to further work in atomic energy in the two countries a joint commission consisting of three Norwegian and three Dutch members was set up, and the establishment at Kjeller was incorporated into a Dutch-Norwegian organization called the Joint Establishment for Nuclear Energy Research (J.E.N.E.R.). The first annual report of this organization has now been published*. Mr. Gunnar Randers, who was director of the Norwegian Institute for Atomic Energy (I.F.A.), was appointed director of the Joint Establishment, and, of the original members of the joint commission-Prof. S. Rosseland (chairman), $O$. Dahl, N. Stephenson, Prof. H. A. Kramers, Prof. C. J. Bakker and J. M. W. Milatz-Prof. Rosseland has since resigned as chairman and been succeeded by Prof. B. Trumpy, and Prof. Kramers has died. Since, however, the creation of the Joint Establishment was largely due to Prof. Kramers's initiative, it is most fitting that the annual report should include a photograph of him as frontispiece and commence with a brief appreciation of his high standing both in scientific circles and in the realm of international affairs.

The factual report is preceded by an extract from a lecture delivered by Mr. Randars on September 26, 1952, at the Technological Institute in Belgrade, Yugoslavia, in which he asserted that, though atomic energy research is undoubtedly an expensive item for small countries to undertake, it would be a mistake to believe that they have a choice as to whether they should undertake it or not. Small countries with large shipping interests-for example, Norway and the Netherlands-cannot afford to have the development of atomic ship propulsion come as a surprise to them, and he maintained that a group of small European nations might well, by joining forces, produce one of the best research and development teams for atomic energy.

Details are given, in the annual report, of the construction and operation of JEEP, which was started up on July 30, 1951. It has a graphite reflector of minimum thickness $70 \mathrm{~cm}$. and uses uranium metal fuel rods contained in aluminium tubes. The react or was run mostly with a charge of sixty-two rods (about $\mathbf{2 \cdot 2}$ tons of uranium); but this is considerably below optimum. The maximum powerlevel so far developed is $100 \mathrm{~kW}$. with a neutron flux at the centre of the pile of $3 \times 10^{11}$ neutrons $/ \mathrm{cm} .^{2}$ sec. The year under review was mainly a 'running-in' period for the pile, and therefore relatively little chemical work was required; but since the pile is well suited, from a technical point of view, for the production of radioisotopes, some research of a chemical nature has been started temporarily by the Isotope Section. It is hoped that when a regular isotope production is achieved at Kjeller, the import and distribution of isotopes from Britain, Canada and the United States, organized by the Joint Establish-

* Joint Establishment for Nuclear Energy Research. First Annual
Report, 1951 52. Pp. 26. (J.E.N.E.R., Kjeller, pa. Lillestrøm, 1952.) 